Winter 2004

\title{
From Empire to Globalization: The New Zealand Experience
}

Janet McLean

University of Auckland

Follow this and additional works at: https://www.repository.law.indiana.edu/ijgls

Part of the International Law Commons

\section{Recommended Citation}

McLean, Janet (2004) "From Empire to Globalization: The New Zealand Experience," Indiana Journal of Global Legal Studies: Vol. 11 : Iss. 1 , Article 7.

Available at: https://www.repository.law.indiana.edu/ijgls/vol11/iss1/7

This Symposium is brought to you for free and open access by the Law School Journals at Digital Repository @ Maurer Law. It has been accepted for inclusion in Indiana Journal of Global Legal Studies by an authorized editor of Digital Repository @ Maurer Law. For more information, please contact rvaughan@indiana.edu.

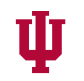

JEROME HALL LAW LIBRARY

INDIANA UNIVERSITY

Maurer School of Law
Bloomington 


\title{
From Empire to Globalization: The New Zealand Experience
}

\author{
Janet McLean*
}

\section{INTRODUCTION}

What does nationhood mean, what do national courts do and what effect have the pressures of globalization had on the meaning of nationhood and the role of national courts? I want to bring a small commonwealth country perspective to these questions in order to suggest that the experiences of empire and globalization may share important elements in common.

Nationalism is not, of course, an incontrovertible good. Some of the worst atrocities of our recent history have been visited on peoples in its cause. For small countries in the commonwealth such as New Zealand, becoming a fully selfgoverning nation was held out as something to aim for, a glittering prize for proving oneself as loyal, responsible, and having learnt well the art of British government. In the colonial context, nationhood has been portrayed as an idealized goal. By the time New Zealand achieved the formal goal of nationhood, however, the very meaning of nationhood had changed-as it had to do to accommodate the expanded number of states. At the turn of the twentieth century, the British Empire covered one-fifth of the earth's surface: some 11,400,000 square miles and 410 million people. ${ }^{1}$ Acknowledged states numbered only fifty. Now there are nearly 200 states. 'Nationhood' for newcomers to the "family of nations" could not but be shaped by the history of the Empire itself.

I begin by tracing New Zealand's (often ambivalent) progress from Dominion to nation-state status during the course of the twentieth century. I go on to suggest that the increasing impact of international human rights and economic agreements on New Zealand's legislature and courts means there is no "national

\footnotetext{
*Faculty of Law, The University of Auckland. This paper was originally presented at a conference entitled Globalization and the Courts, Indiana University, April 2003. Thanks to Hannah Buxbaum for her helpful commentary, Rt. Hon. Sir Kenneth Keith and Treasa Dunworth for comments, and Mark Utting for research assistance.

1. The Roman Empire covered 1,600,000 square miles and comprised 85 million people. Estimated figures taken from The Round Table Studies. An Analysis of the System of Government Throughout the British Empire, at v (MacMillan and Co., Ltd., 1912).
} 
law" meant in a discrete and autonomous sense. How much "international" law is adopted rather than imposed is more difficult to assess. What is clear is that the early twentieth century version of the nation-state has evanesced.

\section{The British Empire and New Zealand}

Nationhood needs to be understood not only in relation to what national courts do but also by reference to how much autonomy executive governments and legislatures enjoy. Under the law of the British Empire, there was only one sovereign and its citizens shared a single nationality-that of British subjects. ${ }^{2}$ When Britain engaged in war, New Zealand joined under British Command (up until World War II). The conceptual unity of the British Crown also encouraged economic interdependence. The British Empire was one large trading bloc. Dominions and former colonies produced food and other commodities to the specifications of the home country. ${ }^{3}$

As Dominions such as Canada, Australia, and New Zealand proved themselves in war, administration, and politics, the concept of a separate and divisible Crown eventually emerged. This was only recognized legislatively in the Royal Titles Act of 1953 (U.K.), which allowed the Queen to hold separate titles in right of different territories. Until that time all the countries in the Commonwealth were represented by a single head of state unified in both a single person and a single office. After 1953, although the person of the sovereign was the same, the office could be considered distinct in relation to the distinct territories. Of course, as with much of British constitutionalism, the formal legal position did not necessarily reflect the actual political position. The single sovereign of the self-governing dominions received separate advice from local advisors through her representative Ministers. The executive and prerogative powers were very

2. As late as 1932, Viscount Dunedin confirmed there was a single, universal Crown. In re Silver Bros Ltd: A-G (Quebec) v. A-G Canada [1932] A.C. 514 (PC). The law refused to personify and incorporate the empire as a whole or any of its component parts. The Crown or King was its representative so that the property and liabilities of (for example) the government of New South Wales were, in law, those of the British Crown. See Williams v. Howarth, [1905] A.C. 551, 553. The concept of an indivisible sovereign also had the effect that the various parts of the Empire could not take legal action against each other. The sovereign could not contract with itself or otherwise enjoy distinct legal personality. Sloman v. Gov't of N.Z. [1876] 1 C.P.D. 563, 567.

3. See James Belich, Paradise Reforged: A History of the New Zealanders, at ch. 8 (2001). 
real measures of independence and the common law constitution still recognizes this-a point to which we shall return. ${ }^{4}$

Neither were the legislatures of the various colonies fully sovereign. The New Zealand Constitution Act of 1852 (U.K.) established the New Zealand General Assembly (later the House of Representatives), which was empowered to make laws for "peace order and good government" of New Zealand. ${ }^{5}$ However, such laws were void if found to be "repugnant to the laws of England." ${ }^{\prime \prime}$ 1931, New Zealand was offered the opportunity to become fully self-governing by the 1931 Statute of Westminster. ${ }^{7}$ New Zealand did not adopt the statute until 1947. But it was not until the passage of the Constitution Act of 1986 (N.Z.) that the New Zealand Parliament was declared to be fully independent as a legal matter. Passed without fanfare, celebration, or revolution, the Constitution Act essentially aligned the legal position with long-established political fact. It stated that the United Kingdom statutes, the New Zealand Constitution Act of 1852 (U.K.) (and amendments), and the Statute of Westminster of 1931 (U.K.) (which allowed the United Kingdom to legislate for New Zealand at New Zealand's request), "ceased to have effect" as part of New Zealand law. ${ }^{8}$ As with the executive branch of government, the formal legal subordination of the New Zealand legislature had long outlasted changes to political practice. London ceased to intervene in domestic issues decades before the New Zealand legislature attained fully sovereign status. ${ }^{9}$

The internal and external conceptions of New Zealand's status were not the same. It was colonial law and not international law that was the primary means of regulating and maintaining empire. Despite its subordinated status within the empire, New Zealand was one of the original members of the League of

4. Leslie Zines, Commentary to H.V. Evatt, The Royal Prerogative c2-c3 (1987). Separate advice has been a reality at least from the $1920 \mathrm{~s}$.

5. An Act to Grant a Representative Constitution to the Colony of New Zealand, 1852,15 \& 16 Vict., ch. 72.

6. Id. Later, the Colonial Laws Validity Act, 28 \& 29 Vict. Acts, ch.63 (1865), available at http:// www.legislation.act.gov.au/a/db_1778/19870112-2261/pdf/db_1778.pdf, clarified that statutes would be repugnant if contrary to imperial enactments and orders but not the common law.

7. Statute of Westminster, 1931, $22 \& 23$ Geo. 5 (Eng.).

8. Constitution Act, 1986, § 26(1) (N.Z.).

9. The influence of the British Parliament did not end in 1947. Major law reform initiatives such as the Crown Proceedings Act of 1950, the Limitation Act of 1950, and the Occupiers Liability Act of 1962 were borrowed from the British law reform template produced by the English Law Reform Committee. 
Nations. New Zealand consistently expressed the desire to belong to something bigger. When New Zealand citizenship first became available in 1947, the relevant Minister Bill Parry explained that "'British Nationality' comes first, and 'New Zealand Citizenship' second." ${ }^{10}$ In 1953, when the New Zealand Prime Minister Sidney Holland visited the White House, he announced: "I have come here to cement British-American relations."

Finally I come to the courts. A Supreme Court Bill (N.Z.) is currently before the New Zealand Parliament that would abolish the Privy Council in London as New Zealand's final appellate court. ${ }^{12}$ The Bill has had a rough passage: many New Zealand lawyers claim that New Zealand cannot and should not do away with the knowledge and assistance of the British Law Lords; others claim that retention of the Judicial Committee as New Zealand's final appellate court is inconsistent with nationhood. ${ }^{13}$

One should not be too quick to treat the continued existence of appeals to the Judicial Committee of the Privy Council as merely a quaint colonial overhang. The institution was intended to serve a serious goal indeed. The British Empire was based on the belief in the importance and robustness of the common law. It was truly to be a "common" law. The gift to the colonies and former colonies of the Judicial Committee of the Privy Council was motivated by a desire to maintain and protect the rights and liberties of British subjects. ${ }^{14}$ In the 1879 case of Trimble v. Hill, their Lordships declared it to be "of the utmost importance that in all parts of the empire where English law prevails, the interpretation of

10. BeLICH, supra note 3, at 319 .

11. Id.

12. At press, the Bill had been passed into law (October 2003) by a bare majority.

13. It is ironic perhaps, that the most eloquent advocate for a distinctive New Zealand jurisprudence, Lord Cooke of Thorndon, spent a number of years after his retirement from the New Zealand Court of Appeal hearing appeals to the House of Lords from England. See Rt. Hon. Sir Robin Cooke, Fundamentals, 1988 N.Z.L.J. 158 (suggesting that the appeal be abolished); see also Rt. Hon. Sir Robin Cooke, A Sketch From the Blue Train, 1994 N.Z.L.J. 10, 14 (emphasizing the need for all democratic nations to contribute to universal human rights law and questioning how English and Scottish Judges on the Judicial Committee can "honestly speak for New Zealand in contributing to an international process?").

14. There were always elements of pluralism within these common law concepts, even if these elements may appear somewhat erratically. Although the common law was always imposed and never voluntarily adopted by indigenous people (unlike civilian codes), the common law always recognized local custom as law and as enjoying a different status than foreign law. See, e.g., Te Weehi v. Reg'l Fisheries Officer [1986] 1 N.Z.L.R. 680 (H.C.). 
that law by the Courts should be as nearly as possible the same." 15 The common law had "globalizing aspirations" and values. ${ }^{16}$

A significant number of commentators have urged that even if Privy Council appeals were to be abolished, a new Supreme Court of New Zealand should include senior judges from other common law jurisdictions or other courts in the South Pacific. Again, I would not be too quick to dismiss this as "colonial cringe," but rather suggest that it reflects a desire to be part of a wider common law culture. ${ }^{17}$

The desire by individual nations within the Commonwealth to develop a distinctive common law has been of relatively recent origin. In the 1980s, the Judicial Committee of the Privy Council implicitly conceded that local custom, statute, "or other reasons peculiar to the jurisdiction" could render English law inapplicable. ${ }^{18}$ In the 1996 case of Invercargill City Council $v$. Hamlin, the Judicial Committee accepted that conditions in New Zealand were sufficiently distinctive to justify the New Zealand courts developing their own approach to the law, even if the rather unlikely subject matter of that case was the liability of building inspectors for defective foundations. ${ }^{19}$ Notwithstanding that the Privy Council has in recent years allowed jurisdictional variation within the common law, there is still a strong tradition in New Zealand of looking to other common law jurisdictions for guidance. English case law is still the most cited body of case law (20\%) after N.Z. case law (70\%) itself; the next most cited jurisdictions are

15. Trimble v. Hill, 5 App. Cas. 342, 345 (P.C. 1879).

16. No wonder then that Britain's acceptance of the supranational jurisdiction of the European Court of Human Rights prompted fears that the decision "would destabilise the colonies." Murray Hunt, Using Human Rights Law in English Courts 33 (3d ed. 1998).

17. See Bernard Brown, After the Privy Council: Returning a Compliment, 1995 N.Z.L.J. 82; see also Lord Cooke of Thorndon, Submission to the Justice and Electoral Select Committee, New Zealand Parliament, on the Supreme Court Bill 2002; David Baragwanath, Towards Maturity in Commonwealth Legal Systems After the Privy Council: An Argument for Cohesion (forthcoming Dec. 2003) (discussing the need for a cohesive common law).

18. Tai Hing Cotton Mill Ltd. v. Liu Chong Hing Bank Ltd. [1986] A.C. 80, 108 (P.C. 1985) (appeal taken from Hong Kong). The Committee stated that the House of Lords, not the Judicial Committee, is the final judicial authority for the determination of English law. The Judicial Committee is able to "depart from a House of Lords' decision ... where by reason of custom, statute, or for other reasons peculiar to jurisdiction where the matter in dispute arose, the Judicial Committee is required to determine whether English law should or should not apply." Id. at 108. The corollary is that unless English law applies, then the common law will be different for each jurisdiction that has its cases decided by the Judicial Committee.

19. Invercargill City Council v. Hamlin, [1996] 1 N.Z.L.R. 513, 519-22 (P.C.). 
Australia (6\%), Canada, and the United States in that order. ${ }^{20}$ New Zealand lawyers are forced by the size of their jurisdiction to be "comparative" lawyersin the past they thought themselves simply to be applying the English common law that was part of New Zealand law.

Despite recent indications to the contrary from some members of the United States Supreme Court, the United States, too, once seemed to more consciously identify itself as part of this wider common law culture. ${ }^{21}$ The Harvard Law Review around the turn of the twentieth century portrays the common law as a more truly unifying language and culture than it is often regarded today. ${ }^{22}$ The fact that the United States does not have a national common law court may be one reason why it does not always so closely identify with the larger common law system. There are undoubtedly other, more substantial constitutional and political reasons for the relative autonomy of the United States common law system, on which I shall elaborate later.

All this is in part by way of introduction. We ought to be wary of suggesting that nationhood and national courts necessarily mean the same thing to newcomers to the family of nations as compared with the colonizing powers and the older, bigger colonies. The experiences of predominately non-European and non-Christian states within the former empire and of indigenous people within the former Dominions are different again. I do not pretend to speak for them. ${ }^{23}$ The colonial legacy manifests itself in a variety of ways in the jurisdiction with which I am most familiar. Compared with more powerful, autonomous, and isolated jurisdictions such as the United States, New Zealand may find the adjustment to an international "globalized" environment a relatively familiar process. It may be easier for New Zealanders than it is for Americans to conceive of a "common law," even if the new common law is now international treaty and

20. See Russell Smyth, Judicial Robes or Academic Gowns? -Citation of Secondary Authority and Legal Method in the New Zealand Court of Appeal, in Legal Method in New Zealand 101, 118 (Rick Bigwood ed., 2001)[hereinafter Legal Method]; see also Rt. Hon. Ivor Richardson, Trends in Judgment Writing in the New Zealand Court of Appeal, in Legal Method, supra, at 261, 263.

21. See Printz v. United States, 521 U.S. 898, 920-21 (1997); see also Knight v. Florida, 528 U.S. 990, 990-91 (1999) (Thomas, J., concurring in the denial of certioriari). But see Anne-Marie Slaughter, A Global Community of Courts, 44 HARv. INT'L L.J. 191, 199-207 (2003) (discussing U.S. judicial efforts to break down barriers between foreign and domestic legal systems).

22. See, e.g., Sir Frederick Pollock, The Continuity of the Common Law, 11 Harv. L. Rev. 423 (1898).

23. See Antony Anghie, Time Present and Time Past: Globalization, International Financial Institutions, and the Third World, 32 N.Y.U.J. INT'L L. \& PoL. 243, 244-45 (2000). 
human rights law, to substitute an idea of cosmopolitan citizenship for panBritish subject status, and to accept supranational tribunals. The habits of mind formed under empire may remain even after the locus of such supranational courts and other institutions has changed. Internationalization may not be so different from empire in terms of its aspirations and motives. Both systems (at their most aspirational) seek peace through interdependence, trade, and the spread of values. The common law, like international economic and human rights law, was viewed as a means of uniting and protecting peoples through the self-conscious dissemination of shared values.

New Zealand is no longer looking steadfastly to English sources of lawbut also further afield to international agreements and international tribunals. International law, not colonial law, dominates. International agreements have increased their coverage of areas of law. The effects of these different areas on national institutions and national legal structures have been, however, very uneven. The most controversial has been the perceived shift of power to the judges in interpreting human rights instruments. The most important economic treaties, by contrast, have received no special attention from our domestic courts. In the economic and environmental fields, the legislature, rather than the judiciary, has been the primary site of controversy.

The explanation for this is pretty simple. The dominant means of enforcing human rights instruments clashes with fundamentals of the British constitutional tradition-with deeply engrained beliefs of the common law. Judges are being asked to limit Parliamentary supremacy in the cause of human rights protection. Economic treaties, by contrast, tend to use predominantly orthodox, positivistic means of implementation. In relation to the economic treaties, it is members of Parliament rather than the judges who are questioning their role. We now consider the impact of international human rights norms and economic instruments on the national psyche, structures, and legal system of New Zealand.

\section{Human Rights Protections}

\section{A. The Commonwealth Models}

The American model of constitutional rights protection has dominated the world since World War II. It is the preferred model for most of the new constitutions. As Stephen Gardbaum suggests, the American model stipulates that legislative supremacy and the protection of fundamental rights are incompatible. 
Fundamental rights must have a higher status than legislation. They must be protected from ordinary amendment and repeal. And it is the Judiciary who must enforce the higher order status of fundamental rights—unreviewed by the legislature. ${ }^{24}$

The American model was of course a direct rejection of the British model and its belief in the capacity of the common law to be the primary defender of liberty. The English common law conception of democracy and parliamentary sovereignty requires that each Parliament be fully sovereign and thus not bound by its predecessors. Every piece of legislation, whether the Dog Act or human rights legislation, should enjoy the same status. Furthermore, judges have a duty to "obey" the law made by Parliament.

It is significant that Canada, the United Kingdom, and New Zealand have responded to the new international human rights era with a brand of constitutional protection that is more consistent with their traditional legal values than with the dominant U.S. model. Each of these jurisdictions has sought to create its own model of human rights protection. While they differ in important respects, each of the three models has in common a desire to create a middle ground between wholesale legislative supremacy and wholesale judicial supremacy. In each model, though, it is the legislature that will always have the final word.

The Canadian model, the Charter of Rights and Freedoms, is closest in form to the United States Constitution. However, the Canadian legislature retains a power to override judicial decisions. ${ }^{25}$ The British Human Rights Act of 1998 is an ordinary statute that exhorts judges to read other statutes consistently with the rights and freedoms protected therein. ${ }^{26}$ When a consistent interpretation is impossible, the Human Rights Act empowers the judges to make a "declaration of inconsistency" and sets out a procedure by which a Minister can fasttrack amendments to an offending statute to ensure its future consistency. The Act does not require that such amendments be made and it remains to be seen how the political practice will evolve. The New Zealand Bill of Rights Act of 1990 is the most traditional of the three in terms of its adherence to a Diceyan

24. Stephen Gardbaum, The New Commonwealth Model of Constitutionalism, 49 Ам. J. Сомр. L. 707, 707-08 (2001).

25. It is a different question whether and when this override power will as a matter of constitutional convention be exercised. Only the province of Quebec has exercised the override power and then only in the early days of the Charter. Id. at 724 .

26. Human Rights Act, 1998, c. 42 \& 3, sched. 2 (Eng.). 
version of parliamentary sovereignty. ${ }^{27}$ Like the English Act, its primary focus is on interpreting statutes consistently with protected rights when it is possible to do so. ${ }^{28}$ The Court of Appeal has, however, suggested that sometimes the Court may have a duty to declare that legislation is inconsistent with the Bill of Rights. ${ }^{29}$ It has not given a declaration so far and there is no mechanism by which a legislative response to a declaration may be fast-tracked. Notwithstanding these variations in the constitutional models, it will depend on constitutional practice or convention how much the legislature of each jurisdiction considers itself bound to comply with the courts' findings. Such conventions are real measures of shared legal culture-legal power and constitutional power do not always reside in the same place under the shared constitutional understandings of the Commonwealth.

Unlike the American model then, the 1990 New Zealand Bill of Rights Act is an ordinary statute and can be amended and repealed like an ordinary statute. The judges cannot use it to strike down legislation for inconsistency. It does impose an affirmative duty on the courts to interpret statutes consistently with rights - a challenge the judges have taken up with some vigor. The judges have also found, but have not yet exercised, a power to make declarations that statutes are inconsistent with rights.

This middle way of constitutional protection (something Chief Justice Marshall thought was impossible $)^{30}$ has been fiercely debated and criticized by all sides. Some claim it goes too far and is an exercise in legal imperialism by the United States, Europe or international bodies; others say it does not go far enough and that New Zealand is consequently in breach of its international obligations. ${ }^{31}$ When New Zealand made its periodic reports to the United Nations Committee on Human Rights in 1995 and 2002, the Committee urged that the New Zealand Bill of Rights be immediately revised "in order to give courts power to strike down

27. See generally Albert V. Dicey, Introduction to the Study of the Law of the ConstituTION (10th ed. 1959) (suggesting that Parliament has an unlimited authority to make laws and that no other body can set aside these laws).

28. New Zealand Bill of Rights Act, 1990, $§ 6$.

29. See Moonen v. Film \& Literature Bd. of Rev. [2000] 2 N.Z.L.R. 9, 16.

30. See Gardbaum, supra note 24, at 108, n.3 (referring to Marbury v. Madison, 5 U.S. (1 Cranch) $137,177(1803))$.

31. Compare James Allan, Rights, Paternalism, Constitutions and Judges, in Litigating Rights 29, 38 (G. Huscroft \& P. Rishworth eds., 2002) with Andrew S. Butler, The Bill of Rights Debate: Why the New Zealand Bill of Rights Act 1990 is a Bad Model for Britain, 17 Oxford J. Legal Stud. 323, 344 (1997). 
or decline to give effect to legislation on the ground of inconsistency with covenant rights and freedoms as affirmed in the Bill of Rights." 32

I take a "middle ground approach" to this "middle ground approach." I have elsewhere sought to explain how New Zealand's administrative law can be used to invalidate unconstitutional applications of statutes without the necessity for a striking down power and how there is real dialogue between courts and legislatures under this model. ${ }^{33}$ I do not intend to rehearse those arguments here except to suggest that the New Zealand version of the Bill of Rights was an attempt to preserve part of New Zealand's common law culture. Even the long title to the Bill suggests that there is continuity with the common law past. It is:

An Act

(a) To affirm, protect, and promote human rights and fundamental freedoms in New Zealand; and

(b) To affirm New Zealand's commitment to the International covenant on Civil and Political Rights. ${ }^{34}$

Attempts to explain the intricacies of the common law culture to the international bodies have largely fallen on deaf ears. The only reason these arguments get any traction at all is that human rights instruments, more than international economic instruments, depend on the existence of states and on their ability to enforce human rights protections for the benefit of their own citizens. ${ }^{35}$ The pressures

32. Concluding Observations of the Human Rights Committee: New Zealand 3/10/1995, $\mathrm{CC}\{\mathrm{R} / \mathrm{C} / 79 / \mathrm{Add} 47 ; \mathrm{A} / 50 / 40$ paras. 176, 185 (1995), reproduced in Human Rights in New Zealand, MFAT Information Bulletin No. 54 (1995), available at http://www.umn.edu/humanrts/ hrcommittee/newzealand 1995.html (last visited Sept. 5, 2003). The gist of these remarks was repeated in 2002. The New Zealand Government reported widespread opposition to an "entrenched" bill vented at a Constitutional Conference in 2001.

33. See Janet McLean, Legislative Invalidation, Human Rights Protection and $s$ of the New Zealand Bill of Rights Act, 2001 N.Z. L. Rev. 421, 423.

34. New Zealand New Zealand Bill of Rights Act, 1990, No. 109 (N.Z.) (emphasis added). The Act goes on to say that "An existing right or freedom shall not be held to be abrogated or restricted by reason only that the right or freedom is not included in this Bill of Rights or is included only in part." Id. at § 28.

35. Even the new International Criminal Court relies on the existing state structure for enforcement. In New Zealand, the jurisdiction of the Court is recognized by the International Crimes and International Criminal Court Act, 2000, $\S 8$ (N.Z.), available at http://www. legislation.govt.nz/(last visited Sept. 5, 2003). 
(including retaliatory measures) that can be put on states to comply are more dilute and diffuse than in the economic setting. And it would be difficult politically to suggest that the United Kingdom, Canada, and New Zealand are the most common perpetrators of human rights abuses. ${ }^{36}$ The New Zealand Bill of Rights Act 1990 was New Zealand's positive law response to international demands that human rights be protected-a response adapted to its legal tradition.

Where the New Zealand system does already contain a structure that can be adapted to give effect to international human rights concerns and that is compatible with parliamentary sovereignty, measures implementing these concerns have been embraced wholeheartedly. New Zealand abolished the death penalty in the 1962 revision to the Crimes Act of 1961 and successive Parliaments have refused to reinstate it, sometimes by reason of the international commitments. New Zealand routinely enacts changes to its statutory law in response to international agreements (most recently in the International Crimes and International Criminal Court Act of 2000 (N.Z.)). It has acceded to the Optional Protocol to the International Convention on Civil and Political Rights, allowing citizens to take claims to the international tribunals after exhausting domestic remedies.

\section{B. Permeating the Common Law with International Law}

Apart from the enactment of positive human rights protections, there have been other developments that have made the common law more permeable to human rights and other international law norms. The orthodox British and, therefore, New Zealand position was that a dualist system operated as between domestic and international treaty law. ${ }^{37}$ The domestic courts were constitutionally bound to give effect to statutes even if such statutes breached the state's international commitments or went beyond the internationally permissible limits of sovereignty. This approach was justified both by the separation of powers,

36. Though it says something about the distorting effects of the international system that Canada is one of the countries most frequently found to be in violation of the International Covenant on Civil and Political Rights by the international body which hears complaints under the Optional Protocol. See J. S. Davidson, Intention and Effect: The Legal Status of the Final Views of the Human Rights Committee, 2001 N.Z. L. Rev. 125, 142 (Canada, France, and the Netherlands rank among the top five countries in quantity of complaints.).

37. Customary international law, in contrast with treaty law, is incorporated or adopted as part of the common law and is part of the law of the land. 
"Parliament and not the executive makes the law," and on the basis of the nonjusticiability of matters within the executive's prerogative power. An established exception to the dualist approach is the common law presumption that Parliament intends to legislate consistently with international obligations. This potentially far-reaching principle was kept in check until recently by the common law rule that only ambiguous (rather than broad or open-textured) provisions should be read consistently with international law norms and commitments. ${ }^{38}$

The recent broadening of that interpretative doctrine to subject broad and open-textured provisions to treaty-consistent interpretations has lead to a requirement that human rights norms must inform the exercise of executive discretion. That interpretative technique has also allowed an expansion of what "human rights" norms may include-in an incremental common law way. ${ }^{39}$ The Tavita line of cases ${ }^{40}$ demonstrates the Court of Appeal's current willingness to refer to the 1989 International Convention on the Rights of the Child when construing discretionary powers under the 1987 Immigration Act. ${ }^{41}$ In the first of this significant line of cases, the Court of Appeal made general observations about the role of international human rights instruments in construing statutory powers. The Department had made the argument that the Minister and his Department were entitled to ignore the international instruments.

38. See Reg. v. Sec'y of State for the Home Dep't ex parte Brind [1991] I A.C. 696.

39. It is not only international human rights norms that have achieved this status in domestic law. In Sellers v. Mar. Safety Inspector [1999] 2 N.Z.L.R. 44, the Court of Appeal considered the relationship between the international obligation to respect the freedom of navigation on the high seas and the domestic legislative requirement that the Director of Maritime Safety must consent to the departure of pleasure craft from New Zealand and must first be satisfied that the pleasure craft and its safety equipment is adequate for the voyage. Mr. Sellers departed New Zealand's shores without complying with the Director's guidelines requiring him to carry a radio and emergency locator beacon. Id. at 46 . The reason given by the director was that New Zealand search and rescue has responsibility for a huge part of the South Pacific. Id. at 48-49. The Court found that the Director's guidelines were in excess of his authority. Id. at 62 . This was achieved by reading down the words 'adequate to the voyage' as 'adequate to the voyage so far as at international law it lies in the power of a port state to regulate this.' See id.

40. See Tavita v. Minister of Immigration [1994] 2 N.Z.L.R. 257; Puli'uvea v. Removal Review Auth. [1996] 3 N.Z.L.R. 538.

41. Immigration Act, 1987, $\S 63$ B (N.Z.). In deciding whether there were exceptional circumstances of a humanitarian nature which would have made it unduly unjust or harsh to remove the applicant from New Zealand, the Associate Minister had not made any reference to the ICCPR or Convention on the Rights of the Child or to the fact of the applicant's marriage and the birth of his child, who had the status of a New Zealand citizen. See Tavita, 2 N.Z.L.R. at 261. 
The Rt. Hon. Justice Cooke-then President of the New Zealand Court of Appeal-said in a much-quoted passage:

That is an unattractive argument, apparently implying that New Zealand's adherence to the international instruments has been at least partly window-dressing. ... For the appellant, Mr. Fliegner drew our attention to the Balliol statement of 1992 ... with its reference to the duty of the judiciary to interpret and apply national constitutions, ordinary legislation, and the common law in light of the universality of human rights. ${ }^{42}$

He went on to say:

[S]ince New Zealand's accession to the Optional Protocol the United Nations Human Rights Committee is in a sense part of this country's judicial structure, in that individuals subject to New Zealand jurisdiction have direct rights of recourse to it. A failure to give practical effect to international instruments to which $\mathrm{New}$ Zealand is a party may attract criticism. Legitimate criticism could extend to the New Zealand Courts if they were to accept the argument that, because a domestic statute giving discretionary power in general terms does not mention international human rights norms or obligations, the executive is necessarily free to ignore them." ${ }^{\text {43 }}$

In rhetorical terms, these statements are revealing not least because they demonstrate some of the self-conscious awareness of a global community of judges and courts that Anne-Marie Slaughter discusses. ${ }^{44}$ Lord Cooke refers explicitly to a meeting of judges held in Oxford in 1992. He clearly considers them to be part of his audience. ${ }^{45}$ In doctrinal terms, these statements can and have

42. Id. at 266 .

43. Id.

44. Slaughter, supra note 21.

45. United States judges have been relatively late in identifying themselves as part of this community. See id. at $216 \mathrm{n} .129$ (referring to a meeting in 1995 as the first World Wide Judicial Conference, meaning this was the first conference that included the United States). For references to other much earlier judicial meetings, see Michael Kirby, The Australian Use of International Human Rights Norms: from Bangalore to Balliol - A View from the Antipodes, 16 U. New S.WALES L.J. 363 (1993). 
been read as being more or less radical. They could be construed, for example, as suggesting that the individual is a subject in international law, and that therefore international law must take precedence over domestic law even in the sphere of nation-states' legal competence. Less radically, they could be used in support of an argument that human rights norms have special status as customary international law, and are therefore part of the common law. ${ }^{46}$ Another, less radical reading would also avoid any conflict with Parliamentary sovereignty. The executive undertook to uphold human rights norms when it ratified the Treaty and therefore when that same executive branch exercises broad statutory powers that require it to address humanitarian concerns, it must do so by reference to international instruments of a humanitarian nature.

\section{Radical Change to the Common Law: Indigenous and Not Imposed?}

All of these developments are attempts to "repatriate" international human rights norms to the common law system in the English tradition. Canada, the United Kingdom, and New Zealand have developed their own national approaches within this broader tradition. They are all attempts to fulfill the promise of the common law to protect liberty and to change without appearing to depart from core tradition. The process of repatriation, however, can also be a process of radical change that effectively remakes the common law. In part these processes are motivated by a desire by some judges to identify the source of the change as internal rather than as completely imposed from the outside.

One important example has been referred to as the "principle of legality." 47 This principle was invoked in cases even before the British Human Rights Act of 1998 came into force in order to give effect to fundamental rights in the face of government policies and practices. What is significant, for our purposes, is that by invoking the principle of legality, as if it were some unifying principle of the common law, the judges reduce the legal importance of positive texts when protecting rights. Constitutions and Bills of Rights, under this view, merely recognize rather than create such rights. ${ }^{48}$ New Zealand Chief Justice Elias has gone so

46. See Murray Hunt, Using Human Rights Norms in English Courts 34 (Oxford 1998).

47. See Reg. v. Sec'y of State of the Home Dep't, ex parte Pierson [1998] I A.C. 539; Reg. v. Sec'y of State of the Home Dep't, ex parte Simms [2000] 2 A.C. 115 [hereinafter Simms].

48. Lord Cooke is explicit about this in Reg. v. Sec'y of State for the Home Dep't, ex parte Daley [2001] 2 A.C. 532,548 n.30. 
far as to suggest that "this principle of legality, recognized by the common law, has been expressly enacted by section 6 of the New Zealand Bill of Rights Act $1990 .{ }^{\prime 49}$ While these statements are not radical in themselves, they sow the seeds for the discovery of a substantive and evolving conception of common law rights and freedoms, and of a substantive version of the rule of law.

The traditional common law view that all statutes enjoy the same status is also being revisited in the new human rights era. Under the traditional conception, in the event of a conflict between statutes, the later statute is taken to have impliedly limited or repealed the earlier one. Even a human rights protecting statute could be limited or amended by implication. This doctrine is no longer good law in Canada ${ }^{50}$ and is being challenged in England and New Zealand. It is now being suggested that there can be a hierarchy of statutes- "ordinary" statutes and "constitutional" statutes. While ordinary statutes may be impliedly repealed, constitutional statutes may not. ${ }^{51}$ Repeal of a "constitutional" statute would require the explicit statement of the legislature, rather than merely an act that was "second in time." The Judges describe this hierarchical view as developing exceptions to the doctrine of implied repeal, which was always the common law's own creature. They describe the change as within the judges' purview, rather than one that is provoked by external forces such as international treaties or human rights norms.

The high water mark of radicalism so far is the dicta of Lord Bingham in Regina v. Lichniak, where he said of 1965 legislation providing for mandatory life imprisonment for murder: "The fact that section (1) represents the settled will of a democratic assembly is not a conclusive reason for upholding it, but a degree of deference is due to the judgment of a democratic assembly on how a particular social problem is best tackled...." 52

Whither parliamentary supremacy?

There can be no doubt that many of the traditional understandings of the common law constitution are being revisited in response to international human

49. See Ngati Apa Ki Te Waipounamu Trust v. The Queen [2000] 2 N.Z.L.R. 659, 675, discussed in Paul Rishworth et al., The New Zealand Bill of Rights (2003).

50. See Re Winnipeg School Div. No. 1 v. Craton [1985] D.L.R. 1.

51. See Thorburn v. Sutherland City Council, 3 W.L.R. 247 (Q.B.D. 2002); Phillip A. Joseph, Constitutional Law, 1 N.Z. L. Rev. 449 (2001) (discussing Chief Justice Elias's analysis of the methodology of repealing unconstitutional legislation in R. v. Pora [2001] 2 N.Z.L.R. 37).

52. Reg. v. Lichniak, 2 W.L.R. 1834, 1840 (H.L. 2002). 
rights norms and that a global community of courts is developing. ${ }^{53}$ In part that serves the important function of portraying these developments as indigenous rather than imposed. It may be that this process can genuinely repatriate international norms to the domestic legal system.

\section{ECONOMIC INSTRUMENTS}

International economic instruments, by contrast, have not been the subject of the attention of national courts, largely because of the means by which they have been implemented. Subject to the exceptions to which I have already referred, New Zealand, like the United Kingdom, is still at least formally a dualist system. Before a treaty becomes law, it must be incorporated into municipal legislation. The debate in relation to the economic treaties has focused on how much Parliament should be able to be involved in the treaty process. The practice has been that Government will negotiate but not become party to a treaty until after the necessary legislation has been passed. The executive is able to pass such legislation in the New Zealand Parliamentary system because, almost by definition, it commands a majority in the House of Representatives. ${ }^{54}$ As a practical and political matter, moreover, a small nation like New Zealand is unlikely to be able to effect many significant changes to a treaty as a matter of negotiation before ratification, even if it wanted to do so. Similarly, reservations are likely to be used only sparingly.

The legislature can be forgiven for being slow to recognize how much the new economic agreements have the potential to limit the future powers of the legislature and executive. Much depends on the detail of how certain economic treaties are enforced. The economic treaties tend to be far less open-textured than the human rights instruments. The first GATT round agreement was enacted in primary legislation and secondary schedules. The next round was implemented largely by amendments to tariff schedules in the Customs and Excise Acts of 1996 (N.Z.). The Executive Council, acting without Parliament, effected those amendments. Anti-dumping and countervailing duty matters are stated as affirmative protections within the Minister of Customs control in the 1996 Dumping and

53. Note that in Simms, supra note 47 , at 696 , the Judges refer to United States freedom of speech jurisprudence, which would have been unheard of twenty years before. $C f$. Reg. v. Sec'y of State for the Home Dep't, ex parte Brind [1991] 1 A.C. 696.

54. Minority governments are also possible. They depend on shifting support. 
Countervailing Duties Act (N.Z.). The Minister was by that Act empowered to supervise whether the WTO agreements are being contravened by exporters to New Zealand. Sanctions are effected by the New Zealand Minister on New Zealand's own local importers by way of increased duties. The reciprocal duties on New Zealand exporters do not require legislative mention and neither does the role of the WTO dispute resolution panels. Other provisions enacting the trade agreements have taken the form of "technical amendments." 55

But other statutes have lately brought these matters more directly to prominence. The Trade Marks Act of 2002 so deeply embeds the Paris or TRIPS agreements into the statutory framework that it cannot be understood without reference to the texts of the international agreements. The legislation's text refers to the agreements without detailing what they say. Indeed, the legislation can never stand on its own because it also refers to the Paris or TRIPS agreements as "revised or amended from time to time." Such integration of the international agreements into the statutory texts raises the conundrum that Parliamentarians are being asked to give legislative recognition to agreements entered into by the executive without even viewing the texts of those agreements, and are then being informed that even if they were to see the text of the amendments it would not be possible to change or modify those texts. What should a nation devoted both to multilateralism and parliamentary sovereignty do?

Even more controversial have been those provisions such as one contained in the New Zealand Climate Change Response Act of 2002 which gives effect to the Kyoto Agreement. It not only incorporates into New Zealand law what has already been agreed to but also gives any future agreements the status of law. It incorporates by reference any future decisions, rules, guidelines, measures or modifications, or agreements made under the Kyoto Protocol. These would automatically receive the legal force of regulations. ${ }^{56}$ The constitutionality of such legislative provisions is doubtful. The Regulations Review Committee of Parliament has sought general advice from various academics and the Legislation Advisory Committee on their validity. ${ }^{57}$ Such advice as it has received has not

55. See, e.g., Agricultural Compounds and Veterinary Medicines Act, 1997 (N.Z.).

56. They would still be subject to the procedure of the Regulations (Disallowance) Act, 1989 (N.Z.), which gives Parliament a chance to supervise the content of secondary legislation. The procedure has never been invoked.

57. See, e.g., Report of the Regulations Review Committee, Inquiry into RegulationMaking Powers that Authorize International Treaties to Override Any Provisions of New Zealand Enactments, N.Z.H.R., 46th Parliament (March 2002). 
stopped these provisions from appearing in legislation. It has resulted, however, in the requirement that the international materials be widely available and disseminated. The courts have not yet been asked to pronounce upon the validity of such provisions. What will happen if an individual is indirectly adversely affected by some ruling made under the framework agreement remains to be seen.

The existence of such provisions can be explained by the structure of many modern treaties. The treaties tend to take the form of umbrella agreements, and set out the agreed processes and mechanisms by which further agreements will be entered. They effectively create webs of agreements.

Back bench members of the governing party and opposition members of Parliament have become increasingly resistant to pressure from the executive to rubberstamp the executive's treaty actions. Parliament has reacted to these developments by changing its internal procedures. In a new procedure trialed since 1998, Parliament's internal rules have required that post-signature but preratification, all multilateral treaties should be presented to the House of Representatives for a select committee to report on a national interest analysis, the extent of the social cultural and economic obligations imposed, the consultations undertaken, and how the agreements should be implemented. The government agrees not to take any further steps in relation to the Treaty during the reporting period. The major political parties have been concerned to achieve a balance between enhancing Parliament's consideration of treaties without derogating from the Crown's ultimate power to become party to a particular treaty. ${ }^{58}$

This reaction has not satisfied some of the smaller parties. A private member's Bill proposed that Parliament should have the power to approve treaties rather than simply enjoy the right to be consulted. This new power would have meant a fundamental break with the constitutional tradition. The concern of the Bill was not only to stop economic treaties having force but may also have applied to the attempts by the courts to incorporate treaty norms into administrative exercises of power. The Bill provided that: "No treaty, or provision in any treaty, has the force of law in New Zealand by virtue of approval given ...."59

58. See generally Treasa Dunworth, Public International Law, 2002 N.Z. L. Rev. 255, 255-61 (providing example situations where Parliament has made treaties); Mai Chen, $A$ Constitutional Revolution? The Role of the New Zealand Parliament in Treaty-making, 19 N.Z.U. L. Rev. 448 (2001) (explaining Parliament's evolving role in treaty-making).

59. International Treaties Bill, cl. 7 (N.Z.)(withdrawn). 
The Bill was defeated by a coalition of the major parties (the parties most likely to lead the governing majority). Disquiet, from within and from without Parliament, continues.

The executive- - by definition commanding a majority in the House-has thus far always been able to use positive means to give effect to international agreements, and to discipline back benchers who would balk at this. Indeed, there still seems to be a consensus that New Zealand is better off joining up to multilateral agreements than not. Bilateralism for a small, relatively powerless country is not an attractive alternative. ${ }^{60}$ Multilateralism is the much better choice. Like belonging to a bigger empire system, it gives a small country like New Zealand more possibility of negotiation and influence, if only at the international level.

It has taken some time for Parliament to become aware of the increasing de facto constraints on its autonomy. Courts have not been asked to address whether Parliamentary sovereignty has substantive as well as formal content and they are unlikely to wish to confine executive treaty-making power. This is in part due to the traditional freedom the executive has enjoyed in international law. Ironically, it is also due to law and practice established in New Zealand's colonial past. The extensive prerogative powers enjoyed by the executive gave New Zealand a large measure of informal independence at a time when it shared the same sovereign as the rest of the empire and its Parliament was subordinated to Westminster. Now that New Zealand has full law-making power, and a separate sovereign, those powers can be used to subordinate the New Zealand legislature to the international law-making system. The legal form may have changed, bur there is a large measure of continuity between empire and globalization.

\section{Conclusion}

Countries such as New Zealand bring a colonial legacy to their experience of nationhood and globalization. New Zealand is used to having its final appellate court sitting in London, composed of Scottish, English, and the occasional New Zealand judge. It has traditionally looked outside its borders at different sources of law-and has actively sought to be part of a broader legal community.

60. Bilateral treaties are becoming more common. 
This colonial experience creates habits of mind that help ease the transition to new supranational tribunals and supranational law.

Globalization has shifted the locus of such supranational tribunals and lawmaking institutions from colonial forums to international forums. New Zealand, like everyone else, has been forced to respond to changes both in the human rights and economic fields. International human rights law has presented the most controversial challenges to the New Zealand domestic system. The dominant U.S. model of rights protection, which gives ultimate power to the judiciary, has been resisted in order to accommodate New Zealand's core constitutional traditions. While the constitutional practice is yet to evolve, Parliament still retains the last word about the proper protection of human rights. At the same time, developments in administrative law have made the common law more permeable to international human rights norms. Other, more radical changes are being wrought to the common law such as the discovery of the "principle of legality" and the creation of an exception to the doctrine of implied repeal. These developments tend to give the impression that the legal source of the judiciary's response to international human rights norms is the common law itself, rather than texts imposed from the outside. In many respects, New Zealand could be said to have a more distinctive common law than it ever had before; to have more "national law," if still in the British common law tradition.

Where the implementation of international economic instruments is concerned, there have been increasing constraints on the autonomy of the legislature. "[S]overeignty appears to be a relatively low-cost means to organize "consent" to international economic treaties. ${ }^{61}$ These are increasingly being presented to the legislature to be rubber-stamped. Paradoxically, in its earlier colonial form the New Zealand legislature enjoyed more political autonomy than the legal position suggested; these days, while it is legally fully self-governing, there are large de facto constraints on that self-government. There is no choice but multilateralism for a small nation like New Zealand.

It may be that the formal "equality" currently enjoyed by nation-states belies pervasive subordination of small states to the larger powers. In this sense, liberals are caught in a bind-we want to say that law, and not power, is the primary regulator of the international system, or else we rob the system of its legal foundation. We need to pretend that the system is "democratic" in a symbolic

61. Benedict Kingsbury, Sovereignty and Inequality, 9 Eur. J. INT'L L. 599, 602 (1998). 
sense. We want to believe that the United Nations Security Council, weapons conventions, and so on that would treat some states rather differently from others are anomalies. To acknowledge too much the role that power plays is to give away the potential for small state participation and real equality.

New Zealand's experience of nationhood and globalization is very different from that of the United States. Perhaps it is in the nature of glittering prizes that they are never quite what they promised to be. The glittering prize of nationhood is no exception. 


\section{HOW GONGRESS WORKS AND WHY YOU SHOULD GARE}

Lee H. Hamilton An inside look at the way Congress works and how it impacts the lives of all Americans, by an eminent former Congressman. cloth $\$ 29.95$ paper $\$ 14.95$

LEE H. HAM ILTON HOW CONGRESS WORKS and

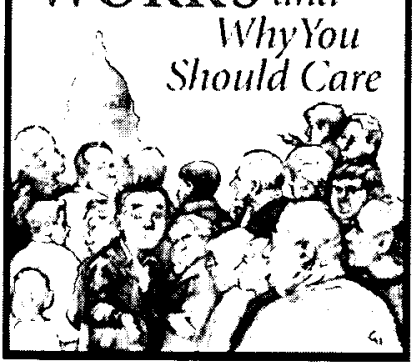

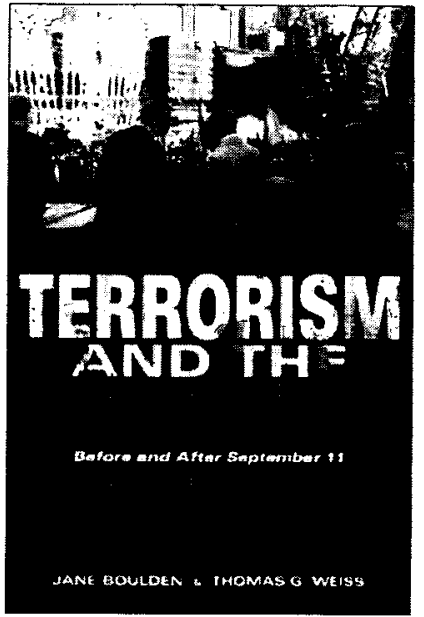

\section{TERBORISMAND THE UN}

Before and After September 11

Edited by Jane Boulden and Thomas G. Weiss

An up-to-date assessment of the UN's changing role in the international war on terrorism.

cloth $\$ \mathbf{6 0 . 0 0}$ paper $\$ \mathbf{2 4 . 9 5}$

\section{RUSSIAN PEASANTS GOTO GOURT}

Legal Culture in the Countryside, 1905-1917

Jane Burbank

A pathbreaking study of the legal culture of Russian peasants in the closing years of the Russian Empire.

cloth $\$ 49.95$ 